\title{
The Potential Role of Colloidal Silica as a Depressant in Scheelite Flotation
}

\author{
Nathalie Kupka *D, Bent Babel and Martin Rudolph \\ Helmholtz Institute Freiberg for Resource Technology, Helmholtz-Zentrum Dresden Rossendorf, Chemnitzer \\ Straße 40, 09599 Freiberg, Germany; b.babel@hzdr.de (B.B.); m.rudolph@hzdr.de (M.R.) \\ * Correspondence: n.kupka@hzdr.de; Tel.: +49-351-260-4486
}

Received: 22 January 2020; Accepted: 5 February 2020; Published: 7 February 2020

\begin{abstract}
The main challenge in scheelite flotation lies in the contamination of the concentrate by other calcium-bearing minerals, mainly calcite. To remedy this problem, sodium silicate is frequently used as a depressant. According to the literature, one hypothesis for the mechanism of water glass consists in its absorption onto calcite through colloidal silica formation, preventing hydrophobization by the collector. This short communication presents research conducted on the direct use of colloidal silica as a depressant in scheelite flotation. Colloidal silica is shown to have an impact on scheelite flotation, especially by depressing silicates.
\end{abstract}

Keywords: scheelite flotation; colloidal silica; depressant

\section{Introduction}

The main challenge in scheelite flotation is the contamination of the concentrate with other semi-soluble salt minerals, mainly calcite, fluorite and apatite, as these minerals display flotation behavior analogous to scheelite due to similar surface properties [1]. Sodium silicate is one of the main depressants against calcite and fluorite used in the scheelite flotation industry [2]. The dosages are very high but selectivity is limited [3], meaning that sodium silicate can sometimes be considered insufficient. The literature describes how water glass can adsorb as colloidal silica in the case of calcite [2,4], preventing the adsorption of the collector. This short communication presents the primary results of research conducted on froth flotation using colloidal silica directly as a depressant.

\section{Materials and Methods}

The ore used for batch flotation tests contained $0.51 \%$ scheelite, $1.70 \%$ calcite, $0.28 \%$ apatite and various silicates (quartz, micas, plagioclases and hornblende) and was of the strata-bound type. Mineral liberation analysis conducted on the ground samples showed that $97.7 \%$ of the scheelite was over $80 \%$ liberated. As a consequence, mineral surface liberation and association did not play a major role in this flotation.

Methods regarding the sampling of pure minerals, microflotation, batch flotation tests and elemental assays are described in detail in Reference [5]. For batch flotation, the ore was ground with a rod mill to a $d_{80}$ of $63 \mu \mathrm{m}$. Froth flotation tests were conducted with $500 \mathrm{~g}$ of ore at $33 \%$ pulp density in a Magotteaux ${ }^{\circledR}$ bottom-driven flotation cell. Each test comprised a single rougher stage, which lasted $7 \mathrm{~min}$ and involved three concentrates with a 5-s scraping rate, $450 \mathrm{~min}^{-1}$ impeller speed and an air flowrate of $5 \mathrm{~L} / \mathrm{min}$. The filtered flotation products were dried overnight in an oven at $50-60{ }^{\circ} \mathrm{C}$, and the mass pull was calculated based on said dried weights. The flotation tests were repeated until the standard deviation of the mass pulls was lower than $4 \%$, while tests that led to an increase in standard deviation over $4 \%$ were rejected. The three points on the diagrams are the cumulative concentrates taken at $t=1,3$ and $7 \mathrm{~min}$. During each batch flotation test, pictures of the side of the transparent 
flotation cell were taken at 2-s intervals with a MoticCam camera with $3 \mathrm{Mpx}$ resolution. The pictures were then processed with Image ${ }^{\circledR}$ in order to extract the froth and bubble information as described by Schach et al. [6]. Statistical analyses of the data were conducted with RStudio ${ }^{\circledR}$. The diagrams present 30-s averages for more clarity.

The reagents used were as follows: sodium oleate $\left(\mathrm{C}_{18} \mathrm{H}_{33} \mathrm{NaO}_{2}\right)$ of $>90 \%$ purity from Carl Roth was used as a collector at a single dosage of $200 \mathrm{~g} / \mathrm{t}$ in order to avoid multicomponent technical grade collectors with effects difficult to evaluate; a complex mixture of glycols, Flotanol $7197^{\circledR}$ from Clariant Mining Solutions, was used as a frother at $20 \mathrm{~g} / \mathrm{t}$; sodium carbonate $\left(\mathrm{Na}_{2} \mathrm{CO}_{3}\right)$ from Alfa Aesar was added before the depressant at a single dosage of $100 \mathrm{~g} / \mathrm{t}$, based on research presented in Reference [7]; analytical grade sodium hydroxide $(\mathrm{NaOH})$ was used as a $\mathrm{pH}$ modifier; sodium metasilicate nonahydrate $\left(\mathrm{Na}_{2} \mathrm{O}_{3} \mathrm{Si} .9 \mathrm{H}_{2} \mathrm{O}\right)$ from Aldrich Chemistry was used as a reference depressant; three colloidal silica solutions from Nouryon (ex-AkzoNobel) were used, namely, Levasil CS30-324 $\mathrm{P}^{\circledR}$, here referred to as CS1, Levasil CS45-38 $\mathrm{P}^{\circledR}$, referred to as CS2, and Levasil CS50-34P ${ }^{\circledR}$, referred to as CS3.

\section{Performance of Colloidal Silica in Scheelite Flotation}

\subsection{Proof of Principle}

Single-mineral microflotation of scheelite and calcite was used to determine if colloidal silica would have any effect on the two minerals (Figure 1). It appears that colloidal silica prevents calcite from floating while scheelite is unaffected by the presence of the reagent, regardless of the dosage. Furthermore, even a small amount of colloidal silica shows an effect on calcite. Based on these results, the authors investigated several parameters related to colloidal silica, namely, its size, its dosage and the effect of $\mathrm{pH}$.

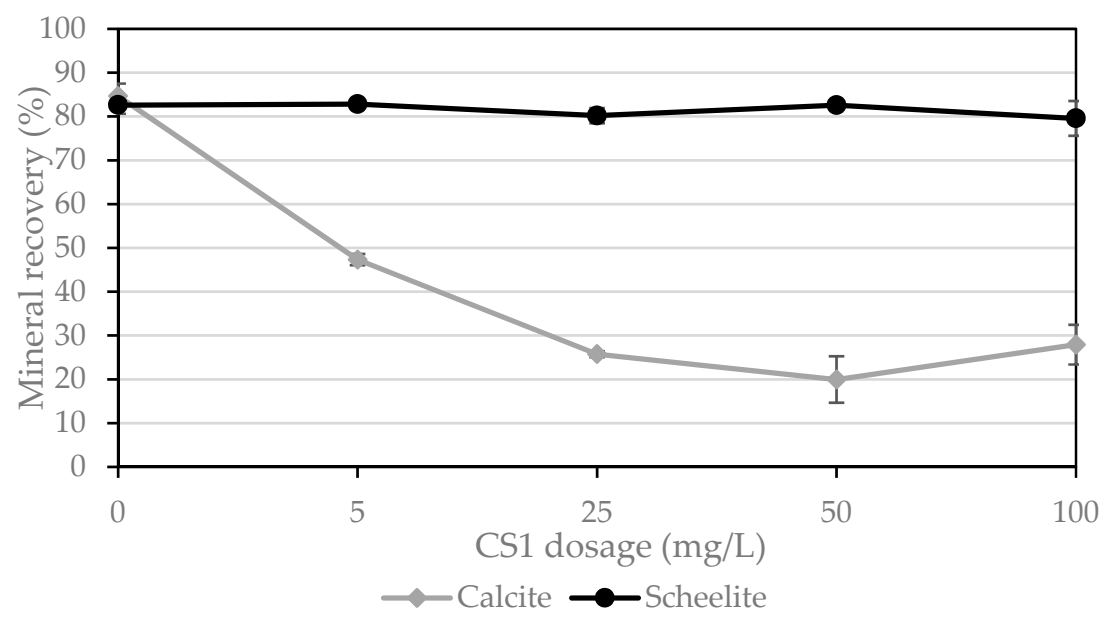

Figure 1. Single-mineral flotation recovery of calcite and scheelite depending on the Levasil CS30-324P ${ }^{\circledR}$ (CS1) dosage (at $\mathrm{pH}=8$, collector $=1 \times 10^{-4}$ sodium oleate, error bars represent the $95 \%$ confidence interval).

\subsection{Impact of Colloidal Silica Size}

According to the manufacturer, the average colloidal silica sizes of CS1, CS2 and CS3 are 9, 30 and $55 \mathrm{~nm}$, respectively. Single mineral microflotations were conducted with CS2 (Figure 2a) and CS3 (Figure 2b). CS2 also affects calcite but higher dosages of the reagent are required, while CS3 shows little effect regardless of the dosage. Based on these results, CS3 was left out of subsequent flotation tests.

To determine if the size of colloidal silica also influences froth flotation, batch flotation tests with CS1 and CS2 at $100 \mathrm{~g} / \mathrm{t}$ were conducted and compared to tests with only sodium oleate as a collector 
and with sodium silicate at 350 and $500 \mathrm{~g} / \mathrm{t}$ (Table 1). Preliminary work with CS1 without repetitions, without sodium carbonate and at $\mathrm{pH} 8$ had shown that dosages at 300 and $500 \mathrm{~g} / \mathrm{t}$ were detrimental to flotation [8], hence the low dosages chosen for this study. The sodium silicate test at $350 \mathrm{~g} / \mathrm{t}$ showed no difference from the reference test with only sodium oleate and is therefore not displayed on the diagrams. Higher dosages of sodium silicate $(1$ and $2 \mathrm{~kg} / \mathrm{t}$ ) resulted in an over-depression of the minerals [7], and $500 \mathrm{~g} / \mathrm{t}$ of sodium silicate is considered optimal for this particular ore.

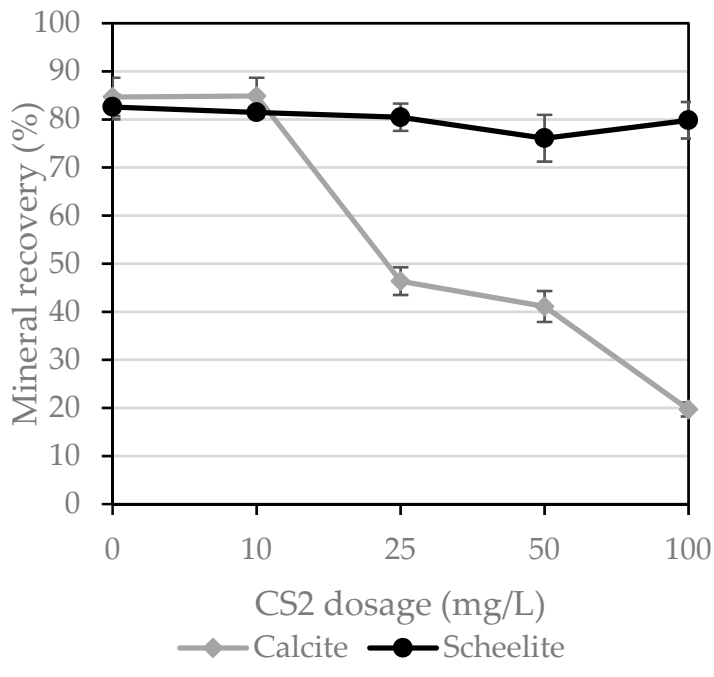

(a)

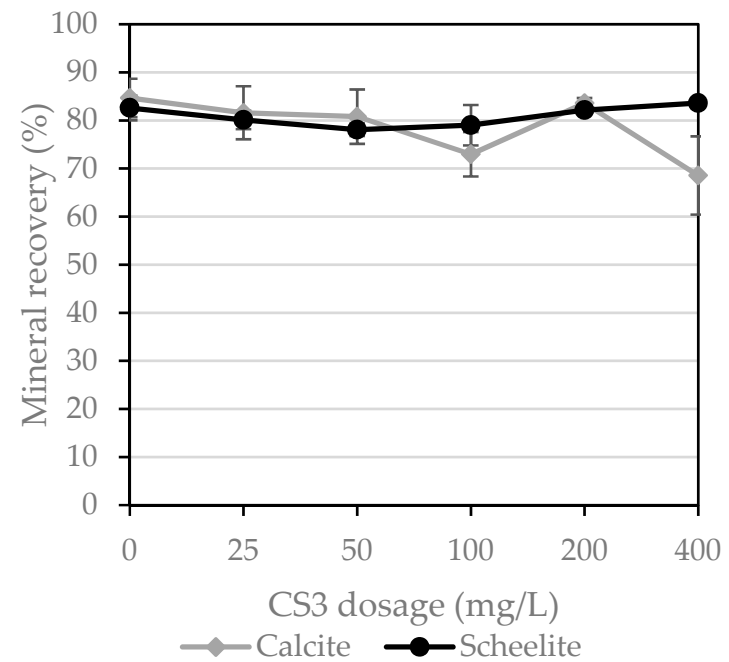

(b)

Figure 2. Single-mineral flotation recovery of calcite and scheelite depending (a) on the Levasil CS45-38P ${ }^{\circledR}(\mathrm{CS} 2)$ dosage and $(\mathbf{b})$ on the Levasil CS50-34 $\mathrm{P}^{\circledR}$ (CS3) dosage (at $\mathrm{pH}=8$, collector $=1 \times 10^{-4}$ sodium oleate, error bars represent the $95 \%$ confidence interval).

Table 1. Batch flotation reagent regime.

\begin{tabular}{|c|c|c|c|c|c|c|}
\hline \multirow{2}{*}{ Test } & \multirow{2}{*}{$\mathrm{pH}$} & \multicolumn{3}{|c|}{ Regulators (g/t) } & \multirow{2}{*}{$\begin{array}{c}\text { Collector (g/t) } \\
\text { Sodium Oleate }\end{array}$} & \multirow{2}{*}{$\begin{array}{c}\text { Frother }(\mathrm{g} / \mathrm{t}) \\
\text { Flotanol } 7197 \text { (Clariant) }\end{array}$} \\
\hline & & Sodium Carbonate & Sodium Silicate & Colloidal Silica & & \\
\hline Ref_NaOl & 9 & 100 & & & 200 & 20 \\
\hline WG_500 & 9 & 100 & 500 & & 200 & 20 \\
\hline CS1_100 & 9 & 100 & & 100 & 200 & 20 \\
\hline CS2_100 & 9 & 100 & & 100 & 200 & 20 \\
\hline
\end{tabular}

Mass pulls, water pulls and tungsten grade-recoveries are presented in Figure 3. In general, the presence of a depressant leads to a more stable froth compared to Ref-NaOl, as for the same water pull, the mass pull is higher. This does not translate into a concentrate of lower quality: the tungsten grades and recoveries are higher, with a higher selectivity for sodium silicate.

Data on calcium and silicates show this higher selectivity for sodium silicate (Figure 4) and show that both colloidal silicas are not distinguishable from each other. The presence of colloidal silica at $100 \mathrm{~g} / \mathrm{t}$ does not prevent the flotation of silicates even if the selectivity remains relatively high, including for calcium-bearing minerals.

Two froth properties are presented in Figure 5. Colloidal silica is associated with more stable froths as indicated by the average froth height, which is constantly higher than that of sodium silicate. The large variability in the CS2 data is potentially caused by the short scraping time (5 s), which might indicate a slower rebuild of froth. The corresponding average bubble diameter is indeed smaller for CS2 even though the froth is thicker, which indicates less bubble coarsening than with CS1 and with WG_500. Bubbles increase in size over time, with a constant increase for WG_500 and a sharp increase towards the end of the set time period for the other two tests. In general, this is related to the lower particle load within the froth as reflected in the mass/water recoveries with time, as these are batch tests. 


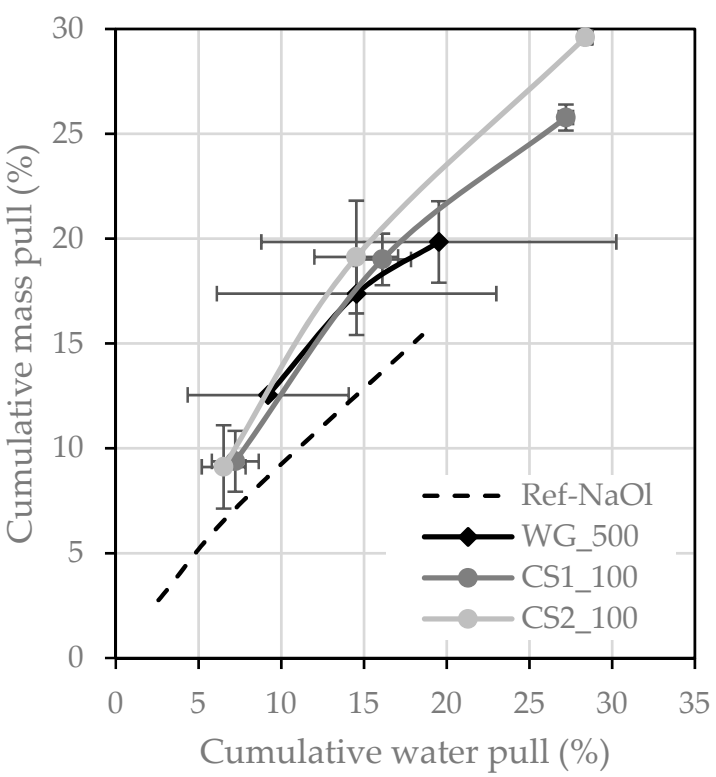

(a)

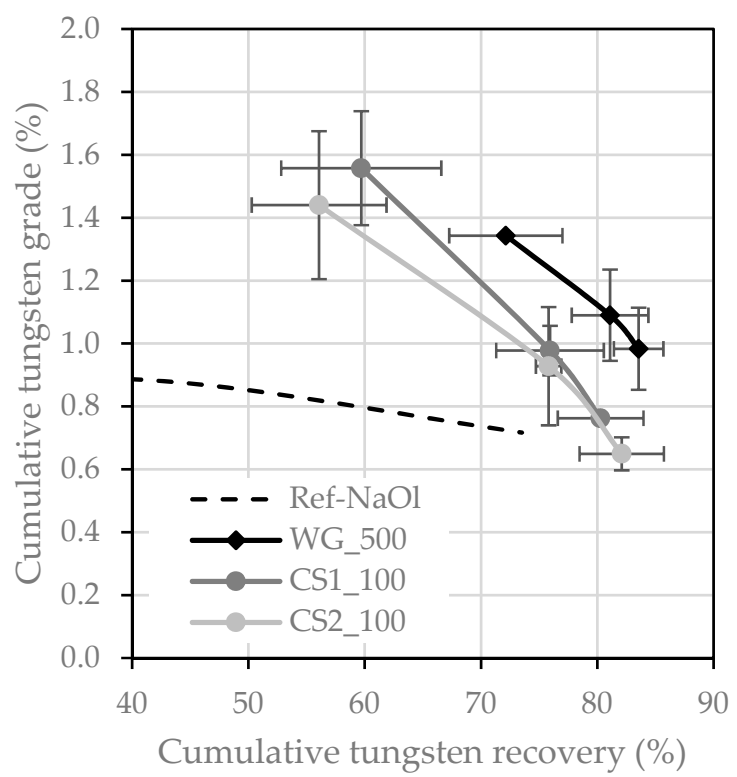

(b)

Figure 3. (a) Mass pull against water pull and (b) cumulative tungsten grade against recovery (error bars represent the $95 \%$ confidence interval).

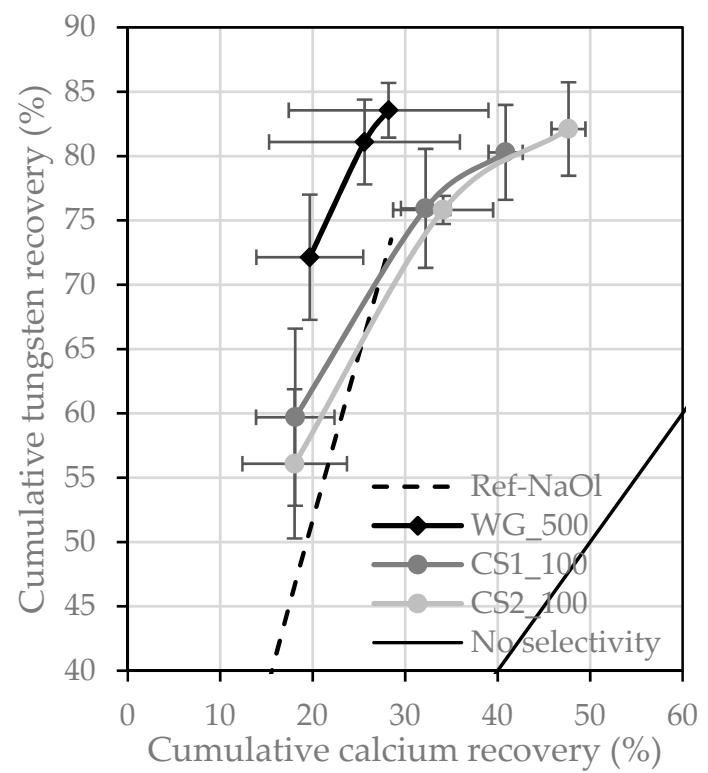

(a)

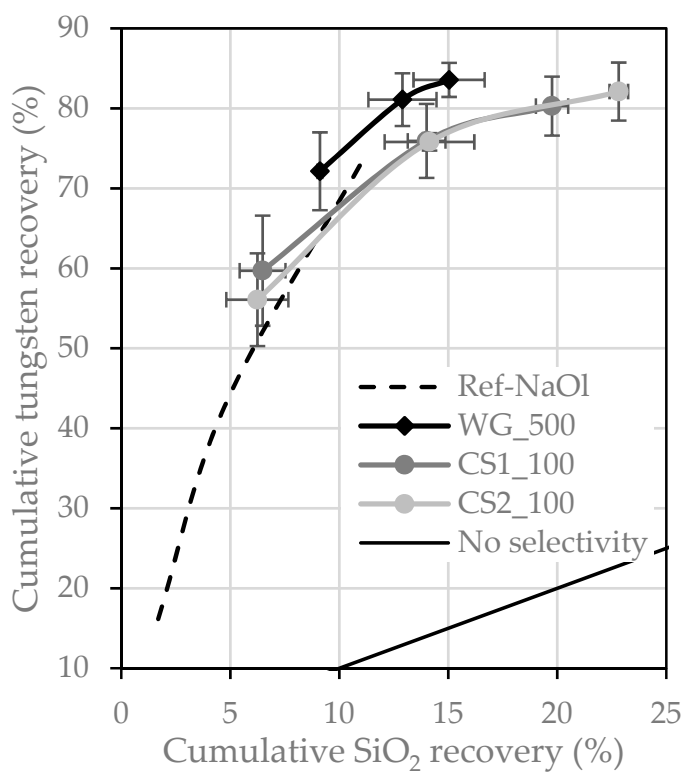

(b)

Figure 4. Selectivity curves of tungsten against (a) calcium (calcium contained in scheelite was subtracted) and (b) silica (error bars represent the 95\% confidence interval). 


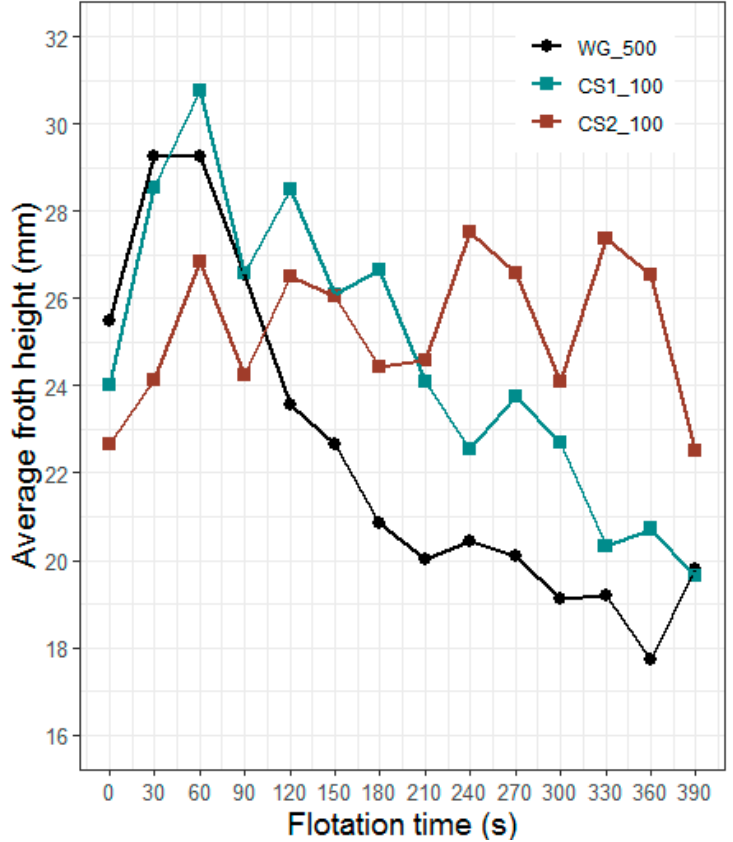

(a)

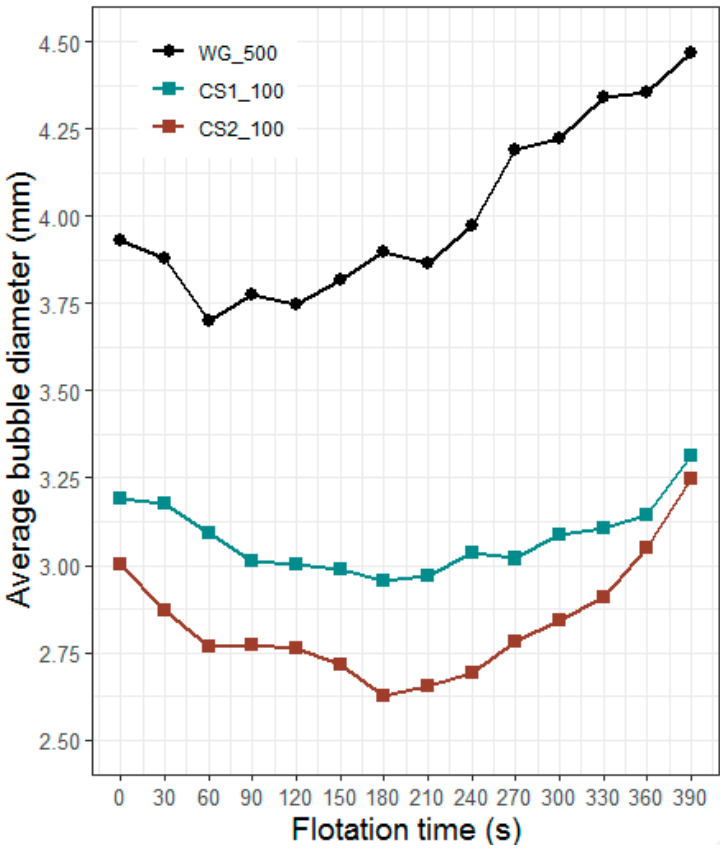

(b)

Figure 5. (a) Thirty-second average froth height and (b) average bubble diameter (by amount of bubbles) over flotation time for WG_500, CS1_100 and CS2_100.

\subsection{Impact of Colloidal Silica Dosage}

One set of tests with CS1 was conducted at a higher dosage of $200 \mathrm{~g} / \mathrm{t}$ (Table 2) to determine the effect of the colloidal silica dosage.

Table 2. Batch flotation reagent regime.

\begin{tabular}{ccccccc}
\hline \multirow{2}{*}{ Test } & pH & \multicolumn{3}{c}{ Regulators $(\mathrm{g} / \mathrm{t})$} & Collector $(\mathrm{g} / \mathrm{t})$ & Frother $(\mathrm{g} / \mathrm{t})$ \\
\cline { 3 - 6 } & & Sodium Carbonate & Sodium Silicate & Colloidal Silica & Sodium Oleate & Flotanol 7197 (Clariant) \\
\hline Ref_NaOl & 9 & 100 & & & 200 & 20 \\
WG_500 & 9 & 100 & 500 & 100 & 200 & 20 \\
CS1_100 & 9 & 100 & & 200 & 200 & 20 \\
CS1_200 & 9 & 100 & & & 200 & \\
\hline
\end{tabular}

CS1_200 is compared to the other tests in terms of mass and water pulls and tungsten grade-recovery curves in Figure 6. Doubling the dosage of CS1 results in mass and water pulls that are very close to those of the Ref- $\mathrm{NaOl}$ test. If the final tungsten recovery is very close, this shows a much higher grade and therefore a more efficient process with higher selectivity.

Indeed, CS1_200 differs from WG_500 by showing less selectivity against calcium-bearing minerals but the same selectivity against silica-bearing minerals (Figure 7). However, compared to the benchmark test with collector only, selectivity is only higher at the beginning of the flotation test.

Figure 8 shows that the froth of CS1_200 is not as thick as that from the other tests; it does not reach a peak at around $60 \mathrm{~s}$ but remains relatively constant. The average bubble diameter is stable over the flotation time and does not increase, where it should normally display higher bubble coarsening as the froth carries fewer particles with time. This is partially linked to the fact that the mass and water pulls are lower for CS1_200 than for the other tests. 


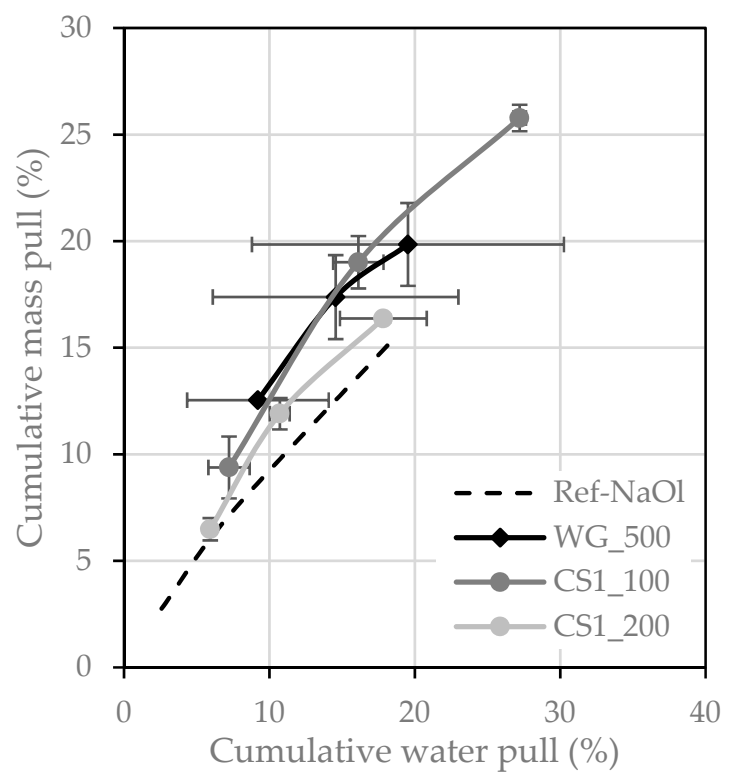

(a)

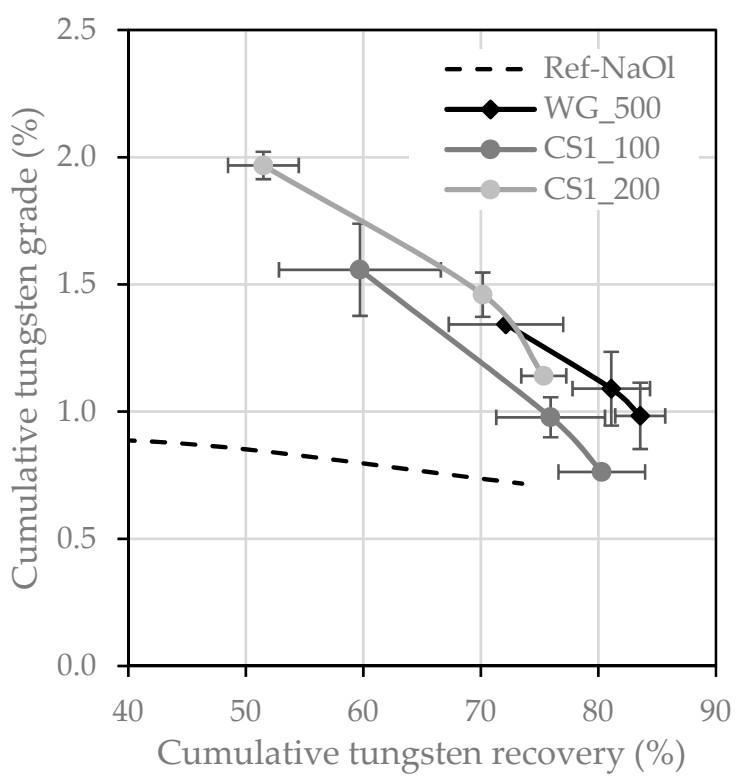

(b)

Figure 6. (a) Mass pull against water pull and (b) cumulative tungsten grade against recovery (error bars represent the $95 \%$ confidence interval).

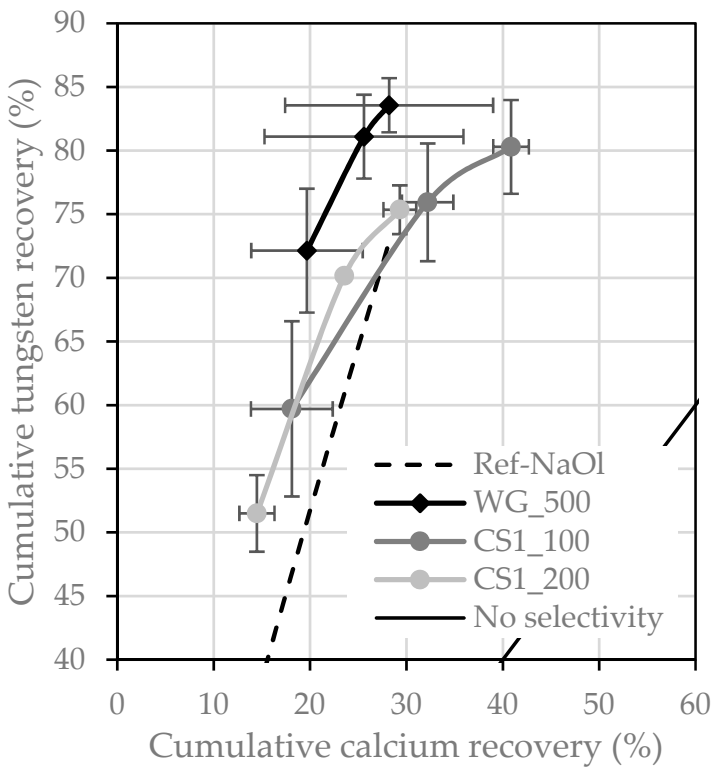

(a)

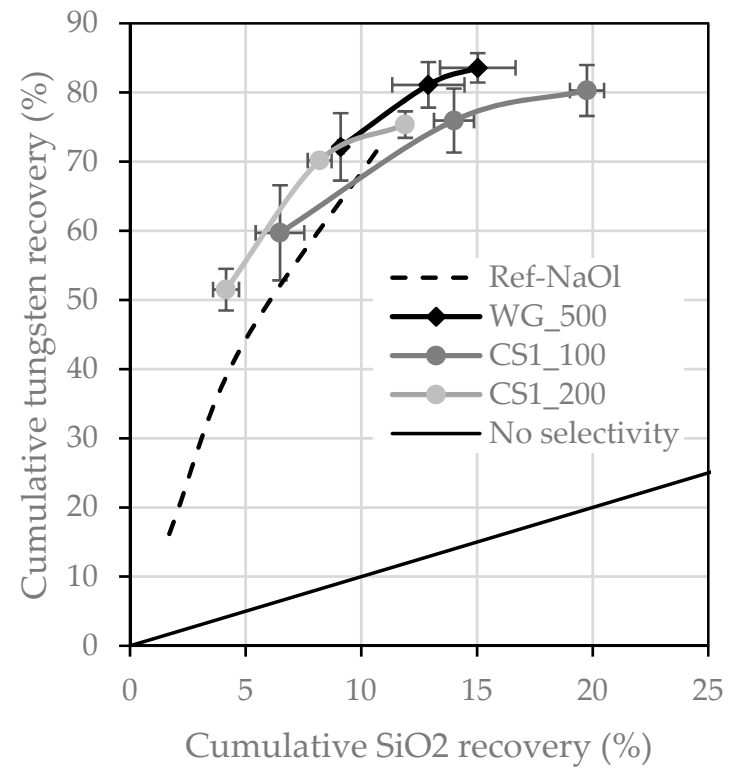

(b)

Figure 7. Selectivity curves of tungsten against (a) calcium (calcium contained in scheelite was subtracted) and (b) silica (error bars represent the $95 \%$ confidence interval). 


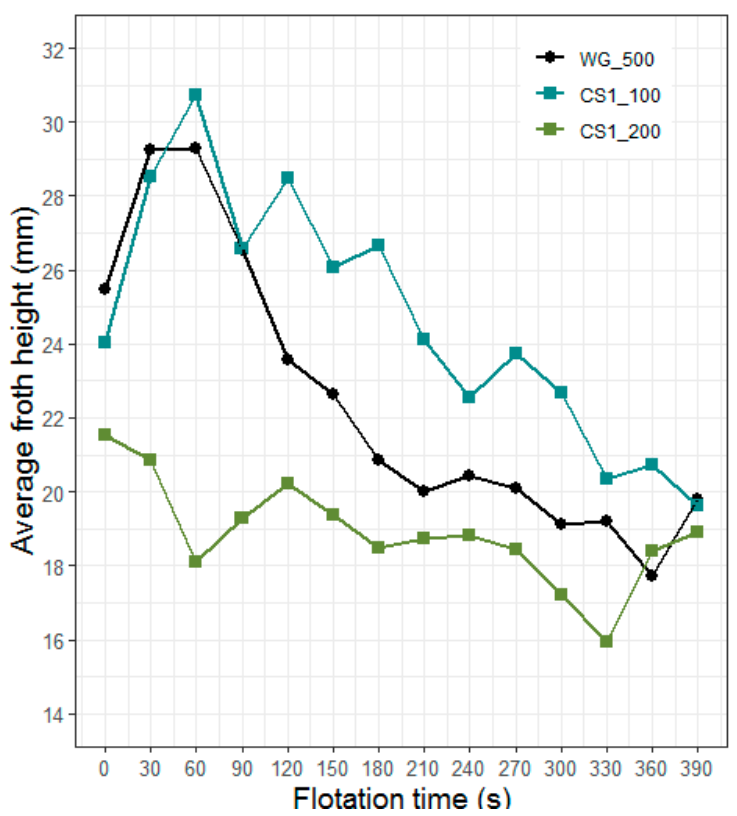

(a)

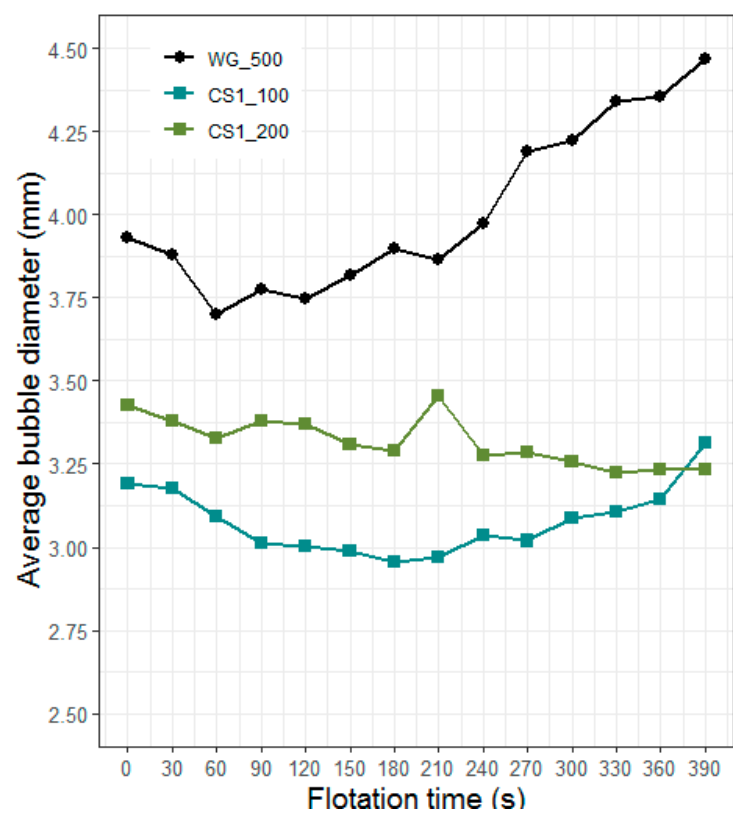

(b)

Figure 8. (a) Thirty-second average froth height and (b) bubble diameter over flotation time for WG_500, CS1_100 and CS1_200.

\subsection{Effect of $p H$}

Single mineral microflotations were conducted at different $\mathrm{pH}$ levels (Figure 9) as the classical scheelite flotation $\mathrm{pH}$ of 9 might be inappropriate. The recoveries of scheelite and calcite remain stable regardless of the $\mathrm{pH}$. Batch flotation tests conducted in different conditions than the ones in this technical note with a CS1 dosage of $300 \mathrm{~g} / \mathrm{t}$ and at $\mathrm{pH} 8,9$ and 10 also showed no impact on the flotation results [8]. Therefore, the action of CS1 can be considered independent of $\mathrm{pH}$ in the case of scheelite flotation.

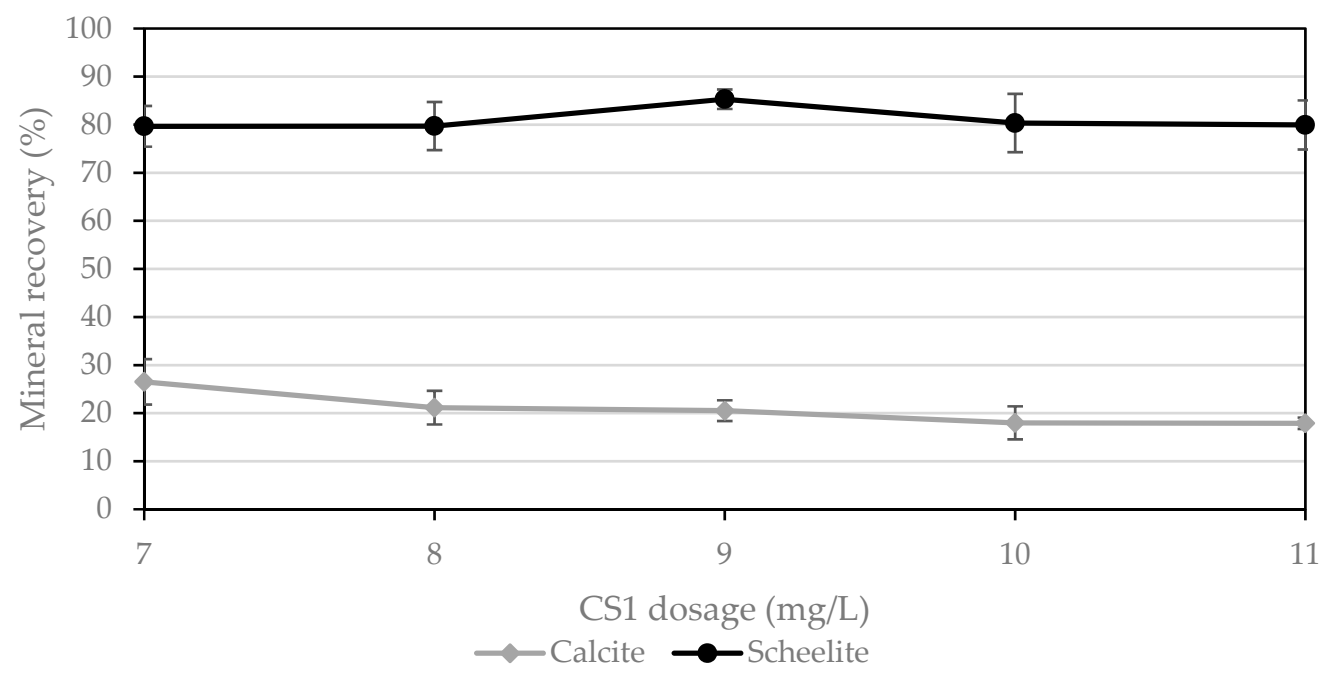

Figure 9. Single-mineral flotation recovery of calcite and scheelite depending on the $\mathrm{pH}$ (collector $=1 \times 10^{-4}$ sodium oleate, depressant $=25 \mathrm{mg} / \mathrm{L} \mathrm{CS1}$, error bars represent the $95 \%$ confidence interval). 


\section{Link to Sodium Silicate}

Silicic acid $\mathrm{Si}(\mathrm{OH})_{4}$ is the main silica species produced by alkaline water glass in solution at a $\mathrm{pH}$ below 9.4; above $\mathrm{pH} 9.4$, it is $\mathrm{SiO}(\mathrm{OH})_{3}{ }^{-}$, and above $\mathrm{pH} 12.6$, it is $\mathrm{SiO}_{2}(\mathrm{OH})_{2}{ }^{2-}$ [9-11]. Many authors have stipulated that these low molecular weight silica species are responsible for the depression effect of sodium silicate [10,12,13]. Fuerstenau et al. [4] suggested in the 1960s that colloidal silica would be the main species responsible for said depression effect.

In principle, the silica species bond with different minerals based primarily on their positive surface charge. In the case of calcium-bearing minerals, for example, the cation $\mathrm{Ca}^{2+}$ is indeed central to the adsorption of silica. Calcite and fluorite have been shown to exhibit a higher calcium surface site density on their surface than scheelite [14,15], meaning they can accommodate more of the silica on their surface. Furthermore, the $\mathrm{Ca}-\mathrm{O}$ or $\mathrm{Ca}-\mathrm{F}$ bond energies have different lengths depending on the mineral, e.g., the shorter the bond, the higher the expected reactivity of calcium. Calcite and fluorite have a similar Ca-X bond length while scheelite's is longer [16-19], so scheelite is not as reactive in the pulp. Finally, the calcium atom is more reactive at a higher dissociated energy of the dangling $\mathrm{Ca}-\mathrm{X}$ bond. The Ca-O bond dissociative energy lies at $383.3( \pm 5) \mathrm{kJ} / \mathrm{mol}$, whereas it is at $529 \mathrm{~kJ} / \mathrm{mol}$ for Ca-F [20]. Consequently, fluorite, then calcite are more attractive chemically than scheelite for the silica species.

Present research tends to show that if colloidal silica may participate in depressing silicates and calcium-bearing minerals, this is most likely a minor effect as compared to the low molecular weight silica species.

\section{Conclusions}

By directly using colloidal silica in the flotation, it was demonstrated that colloidal silica did have an impact on scheelite flotation, even at a low dosage. Required conditions include a fine enough size (below $40 \mathrm{~nm}$ ) and an appropriate dosage, while $\mathrm{pH}$ does not seem to play a role. Further investigations are required before reaching definitive conclusions; however, it appears that froth stability is increased in the presence of colloidal silica. Some of these discoveries were patented in Germany under Patent Nr. 102017 129 673, as colloidal silica has the potential to become a depressant, and not only in scheelite flotation. However, as a synthetic nanopowder, colloidal silica is characterized by high production costs, hence a complementary economic evaluation of the product is planned in order to determine if these costs may be outbalanced by the very low dosages required.

Author Contributions: Conceptualization, N.K. and B.B.; methodology, B.B.; formal analysis, N.K.; investigation, N.K.; writing - original draft preparation, N.K.; writing-review and editing, B.B. and M.R.; visualization, N.K.; supervision, M.R.; project administration, M.R. All authors have read and agreed to the published version of the manuscript.

Funding: This research received no external funding.

Acknowledgments: The authors gratefully acknowledge their research assistants for conducting the microflotation tests.

Conflicts of Interest: The authors declare no conflict of interest.

\section{References}

1. Kupka, N.; Rudolph, M. Froth flotation of scheelite-A review. Int. J. Min. Sci. Technol. 2018, $28,373-384$. [CrossRef]

2. Martins, J.I.; Amarante, M.M. Scheelite Flotation from Tarouca Mine Ores. Miner. Process. Extr. Metall. Rev. 2012, 34, 367-386. [CrossRef]

3. Yongxin, L.; Changgen, L. Selective flotation of scheelite from calcium minerals with sodium oleate as a collector and phosphates as modifiers. I. Selective flotation of scheelite. Int. J. Miner. Process. 1983, 10, 205-218. [CrossRef] 
4. Fuerstenau, M.; Gutierrez, G.; Elgillani, D.A. The influence of sodium silicate in nonmetallic flotation systems. In Transactions; AIME: New York, NY, USA, 1968; pp. 319-323.

5. Kupka, N.; Möckel, R.; Rudolph, M. Acidified water glass in the selective flotation of scheelite from calcite, Part I: Performance and impact of the acid type. Physicochem. Probl. Miner. Process. 2020, 56, 238-251.

6. Schach, E.; Leistner, T.; Rudolph, M. The smaller the valuables, the poorer the recovery-Is that always true? In Flotation, 17th ed.; MEI: Cape Town, South Africa, 2017.

7. Kupka, N.; Rudolph, M. Role of sodium carbonate in scheelite flotation-A multi-faceted reagent. Miner. Eng. 2018, 129, 120-128. [CrossRef]

8. Chinbat, D. Investigation of the depression mechanism of acidified water glass in scheelite flotation. In Helmholtz Institute Freiberg for Resource Technology; Helmholtz Center Dresden-Rossendorf: Freiberg, Germany, 2017; p. 96.

9. Deng, J.; Liu, C.; Yang, S.; Li, H.; Liu, Y. Flotation separation of barite from calcite using acidified water glass as the depressant. Colloids Surf. A Physicochem. Eng. Asp. 2019, 579, 123605. [CrossRef]

10. Feng, B.; Luo, X.; Wang, J.; Wang, P. The flotation separation of scheelite from calcite using acidified sodium silicate as depressant. Miner. Eng. 2015, 80, 45-49.

11. Tian, J.; Xu, L.; Sun, W.; Zeng, X.; Fang, S.; Han, H.; Hong, K.; Hu, Y. Use of $\mathrm{Al}_{2}\left(\mathrm{SO}_{4}\right)_{3}$ and acidified water glass as mixture depressants in flotation separation of fluorite from calcite and celestite. Miner. Eng. 2019, 137, 160-170. [CrossRef]

12. Azizi, D.; Larachi, F. Surface interactions and flotation behavior of calcite, dolomite and ankerite with alkyl hydroxamic acid bearing collector and sodium silicate. Colloids Surf. A Physicochem. Eng. Asp. 2018, 537, 126-138. [CrossRef]

13. Dong, L.; Jiao, F.; Qin, W.; Zhu, H.; Jia, W. Effect of acidified water glass on the flotation separation of scheelite from calcite using mixed cationic/anionic collectors. Appl. Surf. Sci. 2018, 444, 747-756. [CrossRef]

14. Gao, Y.; Gao, Z.; Sun, W.; Yin, Z.; Wang, J.; Hu, Y. Adsorption of a novel reagent scheme on scheelite and calcite causing an effective flotation separation. J. Colloid Interface Sci. 2018, 512 (Suppl. C), 39-46. [CrossRef] [PubMed]

15. Lu, Y.; Drelich, J.W.; Miller, J.D. Oleate Adsorption at an Apatite Surface Studied by Ex-Situ FTIR Internal Reflection Spectroscopy. J. Colloid Interface Sci. 1998, 202, 462-476. [CrossRef]

16. Changgen, L.; Yongxin, L. Selective flotation of scheelite from calcium minerals with sodium oleate as a collector and phosphates as modifiers. II. The mechanism of the interaction between phosphate modifiers and minerals. Int. J. Miner. Process. 1983, 10, 219-235. [CrossRef]

17. Hazen, R.M.; Finger, L.W.; Mariathasan, J.W.E. High-pressure crystal chemistry of scheelite-type tungstates and molybdates. J. Phys. Chem. Solids 1985, 46, 253-263. [CrossRef]

18. Hossain, F.M.; Murch, G.E.; Belova, I.V.; Turner, B.D. Electronic, optical and bonding properties of $\mathrm{CaCO}_{3}$ calcite. Solid State Commun. 2009, 149, 1201-1203. [CrossRef]

19. Saravanan, R.; Israel, S. Bonding in fluorite compound CaF2 using MEM. Phys. B Condens. Matter 2004, 352, 220-226. [CrossRef]

20. Luo, Y.-R. Comprehensive Handbook of Chemical Bond Energies; CRC Press: Boca Raton, FL, USA, 2007.

(C) 2020 by the authors. Licensee MDPI, Basel, Switzerland. This article is an open access article distributed under the terms and conditions of the Creative Commons Attribution (CC BY) license (http://creativecommons.org/licenses/by/4.0/). 